\title{
Design Fabrication and Experimental Investigation of Solar Hybrid Dryer with Biomass Burner
}

\author{
Mr. Pankaj Ramesh Bonde ${ }^{1}$, Prof. Mayur P. Thakur ${ }^{2}$, Prof. Tushar A. Koli ${ }^{3}$, Dr. Vijay H. Patil ${ }^{4}$ \\ ${ }^{1}$ PG student, M. Tech. Department of Mechanical Engineering, Gf's Godavari College of Engineering, Jalgaon, India, \\ ${ }^{2,3}$ Asstt. Professor, Department of Mechanical Engineering, Gf's, Godavari College of Engineering, Jalgaon, India, \\ ${ }^{4}$ Principal, Gf's Godavari College of Engineering, Jalgaon, India, 425001
}

Received on: 16 July,2021

Revised on: 22 August, 2021

Published on: 24 August, 2021

1

\begin{abstract}
Solar-biomass hybrid dryer systems use biomass burners as the back-up source of heat to warm the air prior to charging it in the drying chamber. The flue gas produced from biomass combustion has a considerable amount of heat and is exhausted into the ambient. This project presents a new approach that uses the co-generation (Co-Gen) technique in utilizing the flue gas exhausts from the burner. This approach enhances the circulation of warm air in the drying chamber and eliminates the need for an extraction fan. The exhaust flue is simply injected inside the chimney at the upper part to increase the natural stack effect caused by the rise in temperature and reduction in pressure. This technique is investigated experimentally; the dryer is tested with and without Co-Gen. Aside from the enhancement of efficiency, the main advantage of this approach is the elimination of electricity, given that the Co-Gen replaces the electrical extractor. This advantage renders the hybrid solar drying applicable in rural areas.
\end{abstract}

Keywords- Solar-biomass hybrid dryer systems, biomass burners, co-generation technique, natural stack effect, electrical extractor.

\section{I -INTRODUCTION}

$\mathrm{G}$ rid-connected electricity and supplies of other nonrenewable sources of energy are unavailable, unreliable, or too expensive to many farmers in several rural locations. Crop- drying systems that employ motorized fans or electrical heating are therefore inappropriate in such areas. The large initial and running costs of fossil fuel-powered dryers present such barriers such that they are rarely adopted by small-scale farm owners and operators. The traditional method of open sun drying is widely used by rural farmers but has inherent limitations, such as high crop losses caused by inadequate drying, fungal attacks, encroachment of insects, birds, and rodents, unexpected rains, and other effects of weather conditions. As such, solar crop dryers appear as increasingly attractive commercial propositions.

Due to the energy crisis and environmental pollution issues, many governments are working on developing green energy to alleviate these problems. In the process of drying, it is an effective way for improving the economic efficiency of drying to reduce the energy consumption of drying systems. Drying system energy consumption is mainly affected by the dried product and energy efficiency of the drying system. Hot air convection drying using a traditional energy source is not a sustainable way of drying due to environmental pollution, high investment and operating costs. Solar 


\section{International Journal of Innovations in Engineering and Science, www.ijies.net}

drying has the advantages of being a renewable, free, and abundant energy source, meanwhile, the lowtemperature utilization of solar energy just matches the suitable material drying temperature. However, the practical application of solar drying generally needs to be supplemented by other forms of energy due to the influence of solar energy instability, periodic change, low heat collection efficiency, and so on .Therefore, numerous research works concerning solar drying have been conducted over the past few decades. Solar drying can be divided into four groups: open sun drying, direct solar drying, indirect solar drying and hybrid solar drying. Many researchers have studied the design types of a solar dryer. Solar thermal components are the key to distinguishing different solar drying systems. Hybrid photovoltaic-thermal (PV/T), solar air collector types, greenhouses, etc. have been adopted in previous literature reviews.

Banout et al. ${ }^{[1]}$ designed a new model of double-pass solar drier and tested it under tropical conditions in central Vietnam. Sumit Tiwari, G. N. Tiwari, I. M. AlHelal ${ }^{[12]}$ investigated a forced convection solar greenhouse dryer; this dryer consisted of a solar air collector and chapel-shaped greenhouse. Kabeel and Abdelgaied $^{[13]}$ investigated a new solar dryer with rotary desiccant wheel. The CHP system that combines PV cells with solar water heating is usually referred to as the Solar Photovoltaic/Thermal (PV/T) system. They are well suited for applications where there is a demand for both heat and electrical power and the available roof spaces are limited. The solar drying process is suffering from the lack of sunlight interruption during cloudy and rainy days as well as throughout the night. Integration of the solar dryer with another resource of energy is the most appropriate practical solution to get continuity in drying process. Prasad and Vijay ${ }^{[21]}$ fabricated, and studied natural convection solar dryer coupled with a biomass stove. Brick walls of $(1.45 \times 1.17 \times 0.9) \mathrm{m}^{3}$ surrounded the biomass stove. A burner with a holed tray was provided inside the stove. A $7.5 \mathrm{~cm}$ diameter and $60 \mathrm{~cm}$ long chimney located at one side of the stove to allow the leaving of flue gases. In order to elongate the flow way of exhaust gases and maximize the transfer of heat to the stove walls, three metal baffle plates were inserted. The brick room has 13 rectangular slots with dimension of $0.018 \mathrm{~m} 2$ for fresh air access and one biomass feeding slot with dimension of $0.11 \mathrm{~m}^{2}$. The quantity of $6 \mathrm{~kg}$ charcoal is burned. The temperature measured at the bottom of the tray $59.5^{\circ} \mathrm{C}$.
An indirect natural convection solar dryer integrated with biomass-backup heaters has been designed, constructed and evaluated by Madhlopa and Ngwalo ${ }^{[15]}$. The parts of the biomass burner were composed of drum, rectangular duct and flue gas chimney. The burner was designed with drum length of $0.89 \mathrm{~m}$ and $0.58 \mathrm{~m}$ diameter. The flue gas chimney height was $2.12 \mathrm{~m}$ and diameter $0.12 \mathrm{~m}$. Wood shaving was used as the fuel in the burner. The rate of fuel feeding was $8 \mathrm{~kg}$ per night. The maximum temperature recorded inside the dryer was in the range of 41 to $56^{\circ} \mathrm{C}$.

S. K. Sansaniwal, M. Kumar ${ }^{[10]}$ studied experimentally a mixed-mode natural convection solar collector with biomass burner and heat storage back-up heater. The construction of the biomass burner consisted of a concrete wall surrounded by a thermal storage area that was built using bricks. The chimney was affixed to the upper edge of the stove in such a way that heat from the smoke could heat up the internal wall which would in turn lead to the tray being heated. Shaving wood of 50 $\mathrm{kg}$ was used through night. The temperature measured inside the drying chamber was $65^{\circ} \mathrm{C}$.

Bena and Fuller ${ }^{[20]}$ studied a hybrid drying system. The system consisted of a simple biomass burner combined with a direct type natural convection solar dryer to present a different type of technology for the drying process. The biomass burner, designed mainly to be used with wood as the main fuel for burning, was built from a $0.2 \mathrm{~m}$ drum positioned on its side. Approximately, $9 \mathrm{~kg}$ of wood was burned each night, just enough to keep the temperature inside the dryer under $65^{\circ} \mathrm{C}$.

T. A. Yassen, H. H. Al-Kayiem \& K. Habib ${ }^{[18]}$ reported a design procedure of a thermal back-up system which was flexible to deliver hot flue to dry solid waste or to provide warm air to dry food and fish. The system constructed from biomass burner and gas to gas heat exchanger topping the burner. The design was accomplished to dry $2.5 \mathrm{~kg}$ of palm fiber (EFB). Mathematical model was developed to evaluate the dimensions of the heat exchanger. Results illustrated that heat exchanger of $0.4 \mathrm{~m}$ height and $0.4 \mathrm{~m}$ diameter is enough to produce the required flow rate and temperature of drying air.

\section{II - LITERATURE REVIEW}

Various drying techniques have been employed to dry different types of food and agricultural products. Each drying technique has its own advantages and limitations. 


\section{International Journal of Innovations in Engineering and Science, www.ijies.net}

Choosing the appropriate drying technique is therefore important in the process of drying these perishable products. A solar dryer has been incorporated in the biomass stove to reduce the stove's dependence on solar radiation for its operation and to improve its quality of drying. This approach extends the period of drying of high-value products beyond sunshine hours and possibly during night. Biomass, particularly wood, is a dominant source of energy and is commonly burned using inefficient technologies in most developing countries.

Prasad and Vijay ${ }^{[21]}$ reported the fabrication and test results of an integral-type natural convection of direct solar dryer coupled with a biomass stove. The volumetric flow rate of $0.02 \mathrm{~m}^{3} / \mathrm{s}$ at the maximum dryer temperature of $60{ }^{\circ} \mathrm{C}$ was achieved in the chamber. The overall drying efficiency of the system for drying ginger in the night mode was $7.1 \%$.

Bena and Fuller ${ }^{[20]}$ studied a hybrid drying system, which consisted of a direct-type natural convection solar drying cabinet mounted on top of a brick chamber that enclosed a simple biomass burner. The volumetric flow rate of air exiting from the drying chamber was 0.025 $\mathrm{m} 3 / \mathrm{s}$ at a maximum dryer temperature of $65^{\circ} \mathrm{C}$. The overall drying efficiency of drying pineapple in the night mode was $6 \%$.

Madhlopa and Ngwalo ${ }^{[15]}$ designed, constructed, and evaluated an indirect type natural convection solar dryer integrated with collector-storage solar and biomass backup heaters. Their results showed that the volumetric flow rates were ranged from $0.017 \mathrm{~m} 3 / \mathrm{s}$ to $0.036 \mathrm{~m} 3 / \mathrm{s}$ at the inlet of the dryer, and the overall drying efficiency of the system for drying pineapple in the night mode was $11 \%$.

On the solar collector design integrated with hybrid dryer, Leon and Kumar ${ }^{[16]}$ experimentally investigated a hybrid dryer system that combined an unglazed transpired solar collector, rock bed, and a biomass gasifier stove with a heat exchanger. The system was evaluated by drying chili using air at $60{ }^{\circ} \mathrm{C}$ and $90 \mathrm{~m}^{3} / \mathrm{h}$. The chili was dried from the initial moisture content of $76.7 \%$ to the final moisture content of $8.4 \%$ for $32.5 \mathrm{~h}$ of continuous drying. Then, Leon ${ }^{[16]}$ has designed, developed, and investigated the performance of a renewable energy-based (solar-biomass) hybrid air heating system. The system consisted of an unglazed transpired solar collector (UTC), a rock bed thermal storage, and a biomass gasifier stove with heat exchanger.
Chavan et al. ${ }^{[24]}$ were conducted a mathematical modeling and experimental investigation of a solar biomass hybrid cabinet dryer. Eight trials were conducted for drying mackerel by a solar biomass hybrid cabinet dryer and compared the results with open sun drying at air temperatures of $32.4-57.7^{\circ} \mathrm{C}$, relative humidity $23.9-85.8 \%$, and air flow of $0.20-0.60 \mathrm{~m} / \mathrm{s}$. In conclusion, Madhlopa and Ngwalo ${ }^{[15]}$ suggested recirculating the exhaust gases around the chimney of the dryer to avert reverse thermo-siphoning at night or during periods of low insolation.

M. I. Fadhel, K. Sopian, W. R. W. Daud, M. A. Alghoul [3] experimentally studied the thermal back-up unit (TBU) experimentally, and found that the outlet flue gas temperature reached $160{ }^{\circ} \mathrm{C}$ in delivering hot air temperature of $72{ }^{\circ} \mathrm{C}$ to the dryer, which is suitable for drying most materials. Their conclusion indicates that, in terms of thermal energy waste, the temperature lost in the exhaust flue to the ambient can be utilized by heat recovery. However, the present work presents a method and the results of utilizing the thermal energy in the flue gas in terms of heat recovery by what is named 'the CoGeneration (Co-Gen) technique'. In this technique, the flue gas is directed for injection inside the chimney at the upper part to increase the natural stack effect caused by the rise in temperature and reduction in pressure. This approach to enhance the circulation of warm air (air flow rate) in the drying chamber and eliminates the need for an extraction fan.

The current work experimentally investigates and analyzes the effect of flue Co-Gen on the circulation of air inside the solar-biomass hybrid dryer.

\section{III - METHODOLOGY}

\section{Problem definition and Objective}

The solar drying process is suffering from the lack of sunlight interruption during cloudy and rainy days as well as throughout the night. Integration of the solar dryer with another resource of energy is the most appropriate practical solution to get continuity in drying process. Thus, the hybrid solar - thermal drying techniques are feasible as a practical solution. The present thermal back-up unit is feasible for providing hot air suitable for the drying of any type of agriculture, forest, and food products. The advantage of using such a system is important in the rural areas, where it operates and performs hybrid drying, free of electricity. 


\section{International Journal of Innovations in Engineering and Science, www.ijies.net}

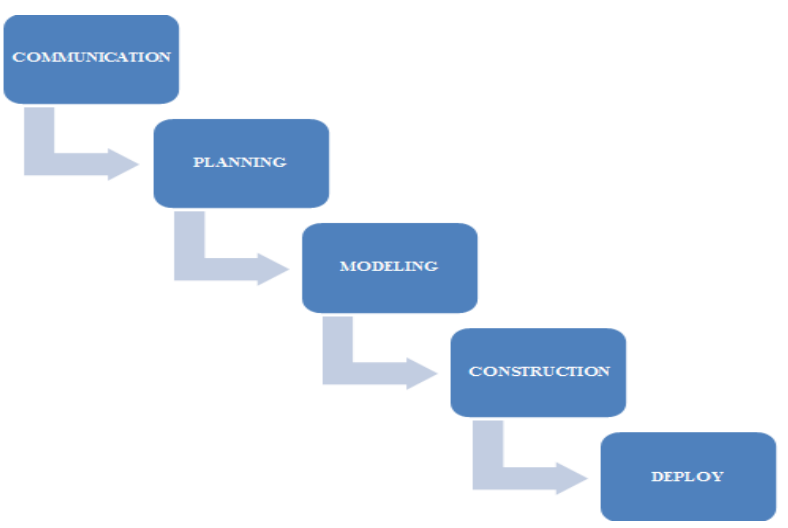

Fig. 1- Waterfall Model

We have decided to complete the project in simple waterfall model

\section{Communication Phase}

Communication phase includes:

- Discussion of topic with guide

- Actual farm visit and understanding various method

- Literature survey

- Problem identification

- Analysis of problem

- Concept development

- Discussing various certainties and uncertainties

\section{Planning Phase}

Planning phase includes:

- Process planning

- Raw material planning

- Force analysis

- Process scheduling

\section{Modeling Phase}

Modeling phase includes:

- Design of various components

- CAD modeling of components

- Assembly model of component

- $\quad$ Prototype model making

\section{Construction and Testing}

- Selection of proper manufacturing methods

- Working as per process scheduling and plan

- Testing of equipment on field

- Error analysis

- Repair if any

\section{Deployment}

- Comparing the project with the designed output

- Preparation of testing results

- Preparation of project report

- Final submission of project

\section{IV-DESIGN}

Frame: - The proper selection of material for the different part of a machine is the main objective in the fabrication of machine. For a design engineer it is must that he be familiar with the effect, which the manufacturing process and heat treatment have on the properties of materials. The Choice of material for engineering purposes depends upon the following factors:

1. Availability of the materials.

2. Suitability of materials for the working condition in service.

3. The cost of materials.

4. Physical and chemical properties of material.

Mechanical properties of material: -

Specification of Bottom

1. Frame Dimension: 36" x 24",

2. Material: MS Angle $20 \mathrm{ft}$.

3. Weight $/ \mathrm{m}: 4.50 \mathrm{~kg} / \mathrm{m}$

4. Total weight of base frame: $9.4 \mathrm{~kg}$

5. Material: Mild steel $5 \mathrm{~mm}$ thick

The mechanical properties of the metals are those, which are associated with the ability of the material to resist mechanical forces and load.

Material used for frames

1. Mild steel

Reasons:

1. Mild steel is readily available in market.

2. It is economical to use.

3. It is available in standard sizes.

4. It has good mechanical properties i.e. it is easily machinable.

5. It has moderate factor of safety, because factor of safety results in unnecessary wastage of material and heavy selection. Low factor of safety results in unnecessary risk of failure.

6. It has high tensile strength.

7. Low co-efficient of thermal expansion.

Designed Components

A) Design of transverse fillet welded joint.

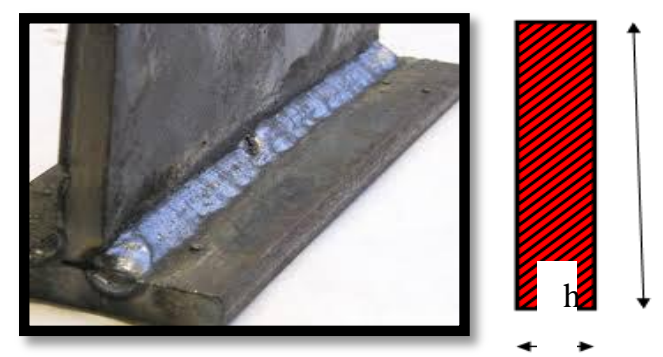

Fig. 2- Welding joint with side view 


\section{International Journal of Innovations in Engineering and Science, www.ijies.net}

Here, $\mathrm{b}=3 \mathrm{~mm} \& \mathrm{~h}=12 \mathrm{~mm}$,

Hence, selecting weld rod size $=3.2 \mathrm{~mm}$

Area of Weld $=0.707 \times$ Weld Size $\times$ L

$$
\begin{gathered}
=0.707 \times 3.2 \times 12 \\
=27.15 \mathrm{~mm} 2
\end{gathered}
$$

Stress induced $=$ Force Exerted $/$ Area of Weld

$$
21=\mathrm{F} / 27.15
$$$$
\mathrm{F}=570.21 \mathrm{~N}=58.12 \mathrm{~kg}
$$

Maximum Allowable Stress for Welded Joints $=21$ $\mathrm{N} / \mathrm{mm}^{2}$.

\section{V-RESULT AND EXPERIMENTAL ANALYSIS}

The system is a hybrid solar-biomass dryer consist of solar collector, drying chamber, thermal back-up unit, and Co-Gen unit. The proposed hybrid drying system was constructed to integrate the mixed-mode solar dryer with TBU. The mixed-mode solar dryer was constructed from a solar collector and direct drying chamber. This dryer was used to deliver the heat to the drying chamber during the day hours. The TBU was constructed from a burner and gas-to-gas heat exchanger.

Solar collector: - A solar collector with a double pass was fabricated from galvanized plate and aluminum angle bars. The absorber plate was fixed between the glass cover and the back of the collector to configure two gaps for the passage of air. The gap between the cover and absorber was set to $0.06 \mathrm{~m}$, and that between the absorber and the back part was set to $0.03 \mathrm{~m}$. The external dimensions of the solar collector were $1.75 \mathrm{~m}$ (length) x $1.1 \mathrm{~m}$ (width) x $0.14 \mathrm{~m}$ (depth). The internal dimensions were $1.75 \mathrm{~m}$ x $1 \mathrm{~m} \times 0.09 \mathrm{~m}$. The back and left and right edges of the solar collector were insulated. The absorber was made of an aluminum plate with a gauge of $0.001 \mathrm{~m}$. The absorber was painted with a mat black color to increase its absorptivity. The dimensions of the absorber were $1.7 \mathrm{~m} \mathrm{x} 1 \mathrm{~m}$. The solar collector tilt angle was $40 \mathrm{o}$ from the horizontal axis.

Drying Chamber: - The chimney had a length of $1 \mathrm{~m}$; fixed on the exhaust of the drying chamber, and connected to a cup. The cup was fixed on top of the chimney to prevent rainwater from entering the chamber and to regulate the flow of the air inside the dryer.

Thermal Back up Unit: - The thermal back-up unit (TBU) was composed of two parts: the lower and upper part (Fig. 2). The lower part consisted of a cylindrical burner for burning fuel and producing flue gas. The mashed plate was fixed inside the burner to hold the fuel. The upper part consisted of the gas-to-gas heat exchanger for heat exchange between the flue gas and fresh air. The burner had a diameter of $0.4 \mathrm{~m}$ and a height of $0.35 \mathrm{~m}$; the gas-to-gas heat exchanger had a length of $0.45 \mathrm{~m}$. The hydraulic diameter of the annulus for the passage of flue gas was $0.1 \mathrm{~m}$, and the hydraulic diameter of the annulus for the passage of air was $0.1 \mathrm{~m}$. The passage for the hot air exhaust from the TBU had a diameter of $0.15 \mathrm{~m}$. The flue gas outlet from the TBU had a diameter of $0.076 \mathrm{~m}$. The exhaust flue gas from the TBU was connected to the chimney of a dryer to produce the up drafting force that enhanced the flow rate inside the dryer. The inlet diameter of the flue gas to the chimney was $0.05 \mathrm{~m}$. The Co-Gen unit is defined as a pipe to pass the flue gas from thermal back-up unit to the dryer chimney. The pipe of an iron type was with an internal diameter of $0.05 \mathrm{~m}$.

Measurement Procedure: - The initial moisture content in the material can be evaluated on a wet basis and stated in percent. A sample of $100 \mathrm{~g}$ (wi) for each experiment was subjected to drying in a convective electric oven, whose temperature was maintained at $105{ }^{\circ} \mathrm{C}$. The weight of the sample was checked every $1 \mathrm{~h}$. When the change in the weight difference was negligible, the process was terminated by switching off the oven, and the final weight of the sample was recorded. The calculated initial moisture content of the red chili using this equation was $233.3 \%$ based on dry basis . Pressure Drop: -

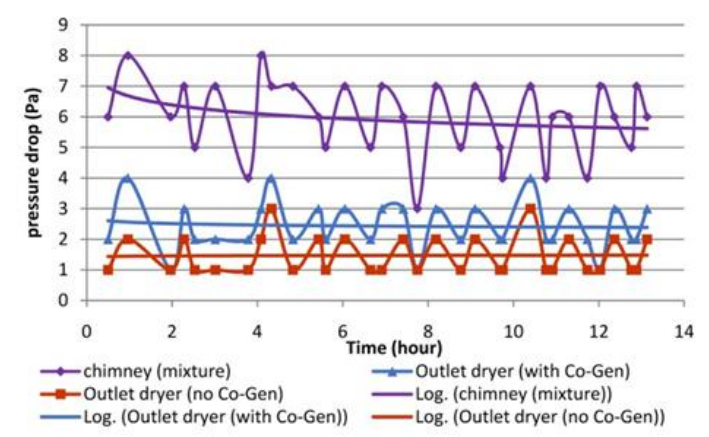

Graph 1 Variation of the pressure drop in the outlet of drying chamber and in the mixture inside chimney with the drying time

The first is the pressure drop between the ambient pressure and the outlet of the drying chamber, with and without Co-Gen, and secondly between ambient and the mixture pressure (flue-air) in the chimney, above the CoGen injection point. It can be seen that the logarithmic mean value of the pressure drop in the mixture zone was in the range of $5.7 \mathrm{~Pa}$ to $7 \mathrm{~Pa}$. For the drying system coupled with Co-Gen unit, the logarithmic mean pressure drop in the outlet of the drying chamber was in 


\section{International Journal of Innovations in Engineering and Science, www.ijies.net}

the range of 2.4 $\mathrm{Pa}$ to $2.6 \mathrm{~Pa}$. For the system without CoGen unit, the logarithmic mean pressure drop in the outlet of the drying chamber was around $1.5 \mathrm{~Pa}$. Therefore, the lower pressure in the mixture zone caused the higher pressure drop in the outlet drying chamber in case of the test with Co-Gen unit compared to the case without Co-Gen unit.

Flow analysis: -

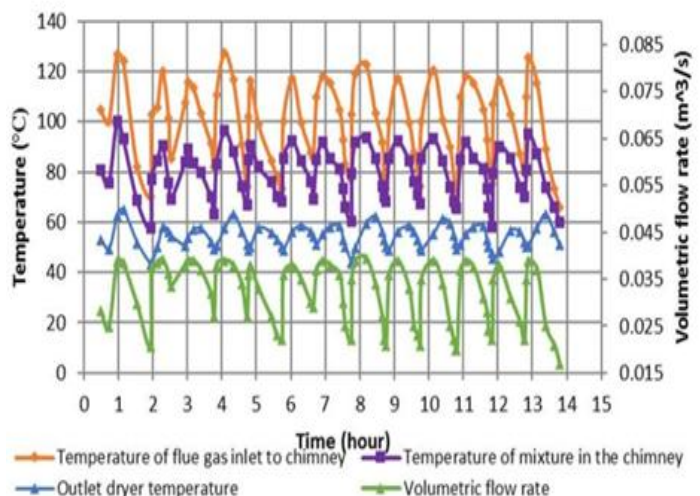

Graph 2 Variation of the temperatures of the flue gas inlet to chimney, mixture in the chimney, outlet dryer, temperature and volumetric flow rate outlet from the dryer with the test time.

The temperature of the mixture (flue gas - air) inside the chimney, the outlet dryer air temperature, and the dryer outlet volumetric flow rate over the test time. The flue gas temperature enter to the chimney was varying from $70.3{ }^{\circ} \mathrm{C}$ to $126.7^{\circ} \mathrm{C}$. The temperature of the mixture in the chimney was found to vary from $57.5^{\circ} \mathrm{C}$ to 100.1 ${ }^{\circ} \mathrm{C}$. When the minimum volumetric flow rate was $0.0206 \mathrm{~m} 3 / \mathrm{s}$, the temperature of the flue gas at inlet to the chimney was $70.3{ }^{\circ} \mathrm{C}$, the temperature of the air exiting from the chimney was $57.7^{\circ} \mathrm{C}$, and the temperature of the air outlet from dryer was $43.3^{\circ} \mathrm{C}$. When the maximum volumetric flow rate was $0.039 \mathrm{~m}^{3} / \mathrm{s}$, the temperature of the flue gas inlet to the chimney was $126.7^{\circ} \mathrm{C}$, the temperature of the mixture in the chimney was $100.1^{\circ} \mathrm{C}$, and the temperature of the air outlet from dryer was $64.9{ }^{\circ} \mathrm{C}$. Hence, the temperature of the mixture in the chimney was higher than the air temperature in the outlet of dryer by $35.2^{\circ} \mathrm{C}$. Therefore, the region of the mixture in the chimney was in a state of low pressure, and the region of the air outlet from the dryer was in a state of high pressure. The air therefore moved from the high-pressure region to the low-pressure region, thereby generating larger up drafting force.

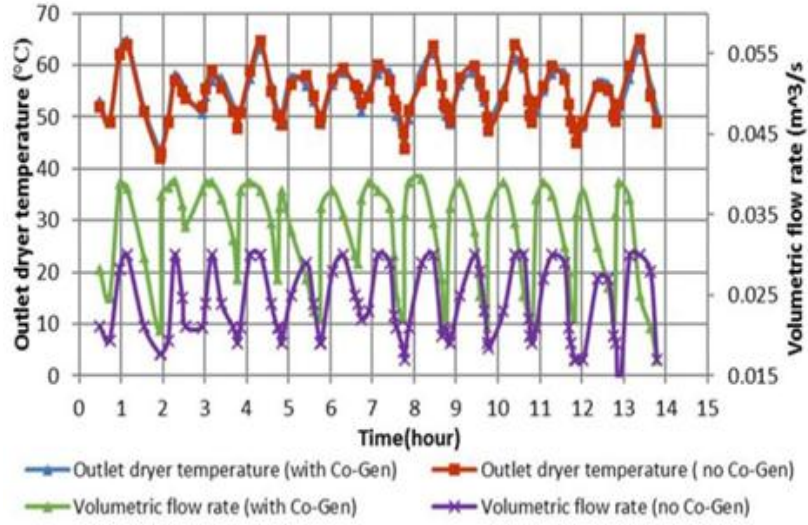

Graph 3 Variation of the outlet dryer temperature and outlet volumetric flow rate with the time of test for case of with and without Co-Gen.

Graph showing comparison of the hydrothermal behavior of the system in terms of the volumetric flow rate and air temperature measured during the experiments of the two cases, with and without Co-Gen. When the temperature was dropped to a low range, which was not suitable for the drying, the burner was fed with fuel to increase the temperature to a range suitable for drying. The volumetric flow rate was estimated from the air velocity in the dryer outlet. For the system without Co-Gen, the air temperature in the outlet dryer varied from $42{ }^{\circ} \mathrm{C}$ to $64{ }^{\circ} \mathrm{C}$ and the volumetric flow rate varied from $0.0178 \mathrm{~m}^{3} / \mathrm{s}$ to $0.03 \mathrm{~m}^{3} / \mathrm{s}$. At the maximum outlet air dryer temperature of $64{ }^{\circ} \mathrm{C}$, the maximum value of the volumetric flow rate was $0.03 \mathrm{~m}^{3} / \mathrm{s}$. The outlet dryer air temperature for the system with Co-Gen varied from $43.3{ }^{\circ} \mathrm{C}$ to $64.9{ }^{\circ} \mathrm{C}$, and the volumetric flow rate varied from $0.0206 \mathrm{~m}^{3} / \mathrm{s}$ to $0.039 \mathrm{~m}^{3} / \mathrm{s}$. Even though the temperature of air outlet from the dryer was much closed in both cases, with and without Co-Gen technique, but the flow rate in case of the system with Co-Gen was higher than in case without Co-Gen by about $23 \%$. So, the Co-Gen enhanced the up drafting inside the dryer, which in turn increased the volumetric flow rate.

Effect of The Co-Gen Technique on the Drying Performance: - Two experiments were conducted to test the effect of the Co-Gen unit on drying. One experiment for drying red chili was conducted with $\mathrm{Co}-\mathrm{Gen}$, and the other without Co- Gen. The effect of the Co-Gen technique was conducted based on the mass reduction, moisture content, drying rate, and overall biomass mode drying efficiency. 


\section{International Journal of Innovations in Engineering and Science, www.ijies.net}

Drying time: -

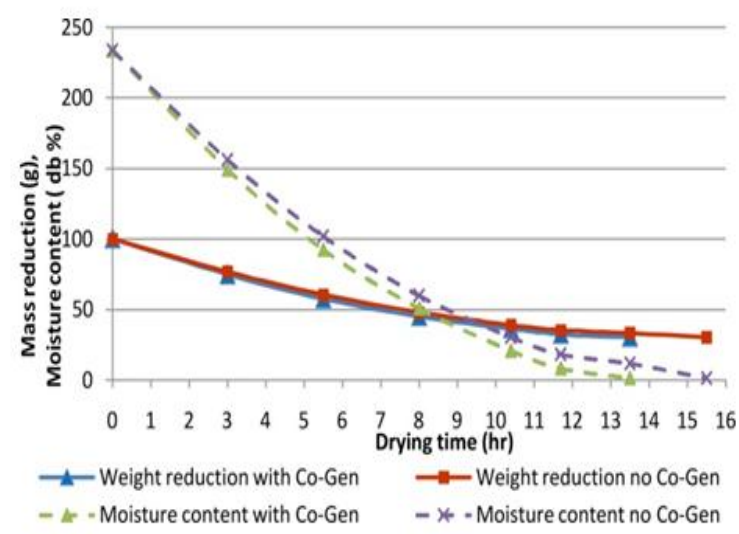

Graph 5 Comparison of the mass reduction and moisture content based on a dry basis of the biomass mode (night mode) of drying chili with and without Co-Gen.

In the night mode drying with Co-Gen, a sample of 100 $\mathrm{g}$ of chili was dried to $30 \mathrm{~g}$ within $13.5 \mathrm{~h}$. In the night mode of drying without Co-Gen, a sample of $100 \mathrm{~g}$ of chili was dried to $30 \mathrm{~g}$ within $15.5 \mathrm{~h}$. The initial moisture content of the sample decreased from an initial moisture content of $233.3 \%$ based on dry basis (equivalent to $70 \%$ based on wet basis) to a final moisture content of $1.43 \%$ (equivalent to $0.43 \%$ based on wet basis) in the system with and without Co-Gen. Drying rate is the main characteristic that is usually used in estimating the performance of any solar drying system.

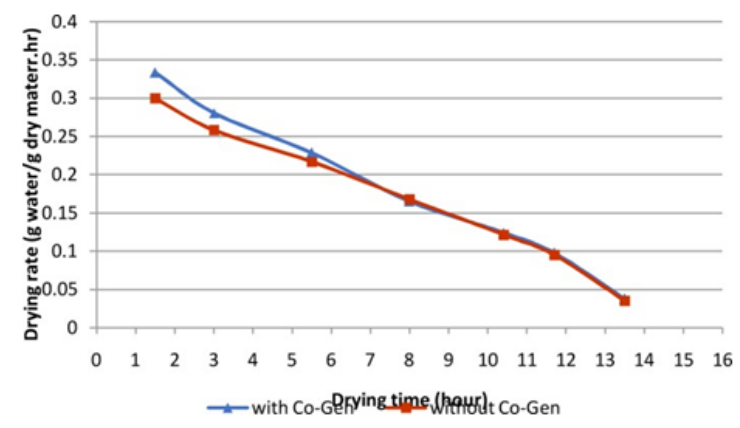

Graph 4 Variation between the drying rate and drying time with and without Co-Gen unit.

In the end of the first $3 \mathrm{~h}$ of drying, the drying rates with and without Co-Gen were 0.28 and $0.258 \mathrm{~g} / \mathrm{g} \cdot \mathrm{h}$, respectively. After $5.5 \mathrm{~h}$, the drying rates with and without Co-Gen were 0.228 and $0.216 \mathrm{~g} / \mathrm{g} \cdot \mathrm{h}$, respectively. Afterward, the drying rates with and without Co-Gen were equal. As well known, there are two basic phases of moisture transfer mechanisms taking place in the drying process. The first is the transfer of the moisture from the surface to the surrounding air, in the form of water vapor, which is a constant-rate phase. Second is the migration of moisture from inside of the drying product to the surface, which is falling- rate period. The first 5.5 hours of drying, the constant-rate period wasn't appeared in the results because it is very short period, due to the nature of the chili, which has thin layer.

Banout et al. ${ }^{[1]}$ reported that there is no constant-rate period has been observed during chili drying while drying took place only in the falling-rate period. Therefore, it can be observed that only the failing-rate period for drying red chili. During the second 5.5 hours, also the failing-rate period took place but it became slower in term of drying rate due to the low flow of moisture from mass interior. The last 2 hours, which was the end of falling-rate period, still some moisture inside the product. Hence moisture content movement took place slowly by diffusion and the drying was terminated. Also, during this period, the drying rate for the system with and without Co-Gen unit was similar. Therefore, it can be conclude that during the first $5.5 \mathrm{~h}$, the main parameters that affect the drying are the temperature and the flow rate due to the high moisture content of product; afterwards, only the temperature affects the drying due to the low moisture content.

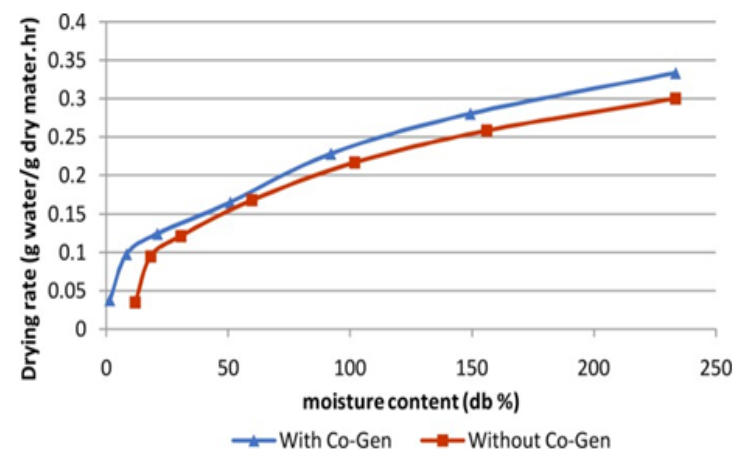

Graph 6 -Drying rate versus moisture content

Drying rate versus moisture content is presented in Fig.6 It could be observed that the higher drying rate at the initial stages of drying which correspond to higher initial moisture content of the product. Also, it could be seen that when the moisture content decreased to around $100 \%$ dry basis, the drying rate becomes similar in the cases of with and without Co-Gen unit.

In the present work, wood was used as the fuel. The calorific value was measured, using a bomb calorimeter, and was equal to $17.295 \mathrm{MJ} / \mathrm{kg}$. In the thermal backup drying experiments, the system with and without the CoGen unit was able to evaporate $3.43 \mathrm{~kg}$ from an initial 


\section{International Journal of Innovations in Engineering and Science, www.ijies.net}

feed of $5 \mathrm{~kg}$ of chili. The weight of the biomass burned to achieve the drying in the system with and without CoGen were 4.7 and $5 \mathrm{~kg}$, respectively. Hence, the energy consumed in case of the system coupled with Co-Gen unit was $16.257 \mathrm{MJ}$ per $1 \mathrm{~kg}$ of product, and in case no Co-Gen, the energy consumed was $17.295 \mathrm{MJ}$ per $1 \mathrm{~kg}$ of product. The efficiencies of the system with and without the Co-Gen unit were $10.5 \%$ and $9.9 \%$, respectively.

Table 1- shows the energy balance for the drying chamber at different drying modes.

\begin{tabular}{|l|l|l|l|}
\hline Experiment type & Energy input & $\begin{array}{l}\text { Energy of } \\
\text { evaporation }\end{array}$ & Energy loss \\
\hline $\begin{array}{l}\text { Hybrid system with } \\
\text { Co-Gen unit }\end{array}$ & $81.28 \mathrm{MJ}$ & $8.57 \mathrm{MJ}$ & $72.7 \mathrm{MJ}$ \\
\hline $\begin{array}{l}\text { Hybrid system } \\
\text { without Co-Gen unit }\end{array}$ & $867 \mathrm{MJ}$ & $8.57 \mathrm{MJ}$ & $77.9 \mathrm{MJ}$ \\
\hline
\end{tabular}

\section{VI- CONCLUSION}

An integral type of mixed-mode solar dryer with TBU was developed for continuous drying. The TBU comprises of a biomass burner and gas-to-gas heat exchanger. A proposed technique to utilize the wasted thermal energy was developed to enhance the circulation of air inside the dryer using the flue Co-Gen technique. Simply, it is re-injection of the hot flue gases in the upper part of the chimney. The contribution of flue CoGen on the circulation of air inside the dryer was investigated using red chili, with an initial moisture content of $70 \%$. The volumetric flow rate was enhanced by $23 \%$ in the system with the Co-Gen technique. The overall drying efficiency by the thermal back mode was $9.9 \%$ and $10.5 \%$ in the system with and without the CoGen technique respectively.

\section{REFERENCES}

[1] J. Banout, P. Ehl, J. Havlik, B. Lojka, Z. Polesny, V. Verner, "Design and performance evaluation of a Double-pass solar drier for drying of red chilli (Capsicum annum L.)", Solar Energy, volume 85, pp. 506-515, 2011.

[2] L. J. Goh, M. Y. Othman, S. Mat, M. H. Ruslan, K. Sopian, "Review of heat pump systems for drying application", Renewable and Sustainable Energy Reviews, Volume-15, pp. 4788-4796, 2011.

[3] M. I. Fadhel, K. Sopian, W. R. W. Daud, M. A. Alghoul, "Review on advanced of solar assisted chemical heat pump dryer for agriculture produce" Renewable and Sustainable Energy Reviews, Volume-15, pp. 1152-1168, 2011.
[4] G. Pirasteh, R. Saidur, S. M. A. Rahman, N. A. Rahim, "A review on development of solar drying applications", Renewable and Sustainable Energy Reviews, Volume- 31, pp. 133-148, 2014.

[5] A. G. M. B. Mustayen, S. Mekhilef, Saidur Rahman, "Performance study of different solar dryers: A review", Renewable and Sustainable Energy Reviews, Volume- 34, pp. 463-470, 2014.

[6] A. Fudholi, K. Sopian, B. Bakhtyar, M. Gabbasa, M. Y. Othman, M. H. Ruslan, "Review of solar drying systems with air based solar collectors in Malaysia" Renewable and Sustainable Energy Reviews, Volume- 51, pp. 1191-1204, 2015.

[7] Mr. T. B. Shaikh, Mr. A. B. Kolekar, "Review of hybrid solar dryers", IJIERT, Volume- 2, issue 8, pp. 37-43, 2015.

[8] A. A. El-Sebaii, S. M. Shalaby, "Solar drying of agricultural products: A review" Renewable and Sustainable Energy Reviews, Volume-16, pp. 37-43, 2016.

[9] Tadahmun A. Yassena \& Hussain H. Al-Kayiema, "Solar-Biomass Hybrid Dryer Enhanced by the CoGen Technique”,Drying Technology: An International Journal, 2015.

[10] S. K. Sansaniwal, M. Kumar, "Analysis of ginger drying inside a natural convection indirect solar dryer: An experimental study", Journal of Mechanical Engineering And Sciences, Volume 9, pp. 1671-1685, 2015.

[11] M. Kumar, S. K. Sansaniwal, P. Khatak, "Progress in solar dryers for drying various commodities", Renewable and Sustainable Energy Reviews, Volume- 55, pp. 346-360, 2016.

[12] Sumit Tiwari, G. N. Tiwari, I. M. Al-Helal, "Performance analysis of photovoltaic-thermal (PVT) mixed mode green house solar dryer", Solar Energy, volume 133, pp. 421-428, 2016.

[13] A.E. Kabeel, Mohamed Abdelgaied, "Performance of novel solar dryer", Elsevier, Volume1, pp. 183189, March 2016.

[14] Clement Adekunle Komolafe1, Mufutau Adekojo Waheed, "Design and fabrication of a forced convection solar dryer integrated with heat storage materials", ACSM Journal, Volume-42, pp. 22-39, March 2018.

[15] A. Madhlopa, G. Ngwalo, "Solar dryer with thermal storage and biomass back-up heater", Solar Energy, volume 81(4), pp. 449-462, 2007.

[16] Mathias Leon, Sivanappan Kumar, "Design and Performance Evaluation of a Solar-Assisted Biomass Drying System with Thermal Storage”, Drying Technology, Volume- 26, pp. 936-947, 2008.

[17] Dronachari M., Shriramulu, "Application of Different Types Solar Dryers in Agriculture Crops- A Review", IJPAB, Volume- 7(2), pp. 303-326, 2019.

[18] T. A. Yassen, H. H. Al-Kayiem \& K. Habib, "Design and performance investigation of a thermal back-up 
Vol. 6 , No. 10, 2021, PP. 154-162

International Journal of Innovations in Engineering and Science, www.ijies.net

system for hybrid drying", WIT Transactions on Ecology and The Environment, Volume- 179, pp. 921-931, 2013

[19] Tadahmun Ahmed Yassen, Hussain H. Al-Kayiem, Khairul Habib, "Evaluation of hybrid solar biomass dryer with no load", MATEC Web of Conferences, 2014.per page.)

[20] Bena, B.; Fuller, R. Natural convection solar dryer with biomass back-up heater. Solar Energy 2002, 72 (1), 7583 .

[21] Prasad, J.; Vijay, V. Experimental studies on drying of Zingiber officinale, Curcuma longa $l$. and Tinospora cordifolia in solar-biomass hybrid drier. Renewable Energy 2005, 30 (14), 20972109.

[22] Tarigan, E.; Tekasakul, P. A mixed-mode natural convection solar dryer with biomass burner and heat storage back-up heater.

[23] Kaygusuz, K.; Türker, M. Biomass energy potential in Turkey. Renewable Energy 2002, 26 (4), 661678.

[24] Chavan, B.R.; Yakupitiyage, A.; Kumar, S. Mathematical modeling of drying characteristics of Indian mackerel (Rastrilliger kangurta) in solarbiomass hybrid cabinet dryer. Drying Technology 2008, 26(12), 15521562.

[25] [25] Augustus Leon, M. Thesis Summary: Theoretical and Experimental Investigation of a Solar-Biomass Hybrid Air Heating System for Drying Applications. Drying Technology 2009, 27(6), 821822. 